\title{
A NEW MEASURE OF VOLATILITY USING INDUCED HEAVY MOVING AVERAGES
}

\author{
Ernesto LEÓN-CASTRO ${ }^{*}$, Luis Fernando ESPINOZA-AUDELO ${ }^{2}$, \\ Ezequiel AVILES-OCHOA ${ }^{2}$, José M. MERIGÓ ${ }^{3,4}$, Janusz KACPRZYK ${ }^{5}$ \\ ${ }^{1}$ Faculty of Economics and Business Administration, Universidad Católica de la Santísima Concepción, \\ 4070129 Concepción, Chile \\ ${ }^{2}$ University of Occidente, Blvd. Lola Beltrán s/n esq. Circuito Vial, Culiacán 80200, México \\ ${ }^{3}$ School of Systems, Management and Leadership, Faculty of Engineering and Information Technology, \\ University of Technology Sydney, Ultimo, 2007 NSW, Australia \\ ${ }^{4}$ Department of Management Control and Information Systems, School of Economics and Business, \\ University of Chile, Av. Diagonal Paraguay 257, 8330015 Santiago, Chile \\ ${ }^{5}$ Systems Research Institute, Polish Academy of Sciences, Neweleska 6 street, 01-447, Warsaw, Poland
}

Received 13 June 2018; accepted 26 January 2019

\begin{abstract}
The volatility is a dispersion technique widely used in statistics and economics. This paper presents a new way to calculate volatility by using different extensions of the ordered weighted average (OWA) operator. This approach is called the induced heavy ordered weighted moving average (IHOWMA) volatility. The main advantage of this operator is that the classical volatility formula only takes into account the standard deviation and the average, while with this formulation it is possible to aggregate information according to the decision maker knowledge, expectations and attitude about the future. Some particular cases are also presented when the aggregation information process is applied only on the standard deviation or on the average. An example in three different exchange rates for 2016 are presented, these are for: USD/MXN, EUR/MXN and EUR/USD.
\end{abstract}

Keywords: volatility, IHOWMA operator, exchange rate, moving average.

JEL Classification: C13, D81, F31, G17.

\section{Introduction}

Volatility is a basic concept in economics for measuring the variance of some variables like exchange rate, stock prices and some other (Garman \& Klass, 1980; Rabbani, Grable, Heo, Nobre, \& Kuzniak, 2017). To calculate the volatility, the coefficient of variation is used in historical data (Minton \& Schrand, 1999), but some researchers have identified other variables that can make the results vary from forecast results, for example: a) in stock markets, Officer

*Corresponding author. E-mail: eleon@ucsc.cl 
(1973) indicates that volatility is related to macroeconomic variables, b) in electoral voting, van Biezen, Mair, and Poguntke (2012) and Hooghe and Kern (2015) found that volatility is related to a decline in party memberships and c) in exchange rate, Aristotelous (2011) says that volatility in exchange rate can be related to exchange-rate regimes.

It is important to note, that volatility is not only influenced by the historical data, but can also be influenced by some macroeconomics variables like GDP, interest rate, foreign reserves and others Grossmann, Love, and Orlov (2014), but also there are some other information that can be added to the results, such as, knowledge of the decision maker about the future scenarios that it is important to add when there is important uncertainty in the problem (Yager, 1996, 2006).

In the context of planning of regional development, Kacprzyk and Straszak (1984) introduced a concept of stability of a regional development strategy to express a natural human bias, both of the regional authorities and inhabitants, that the variability of crucial development indicators (e.g. values of life quality indicators) should be limited, to yield some feeling of "stability". The changes of values of these indicators at consecutive planning stages are then subjected to an objective (against targets set by the authorities) and objective (against expectations of inhabitants) limitations, and then their degrees of satisfaction are aggregated, using both simple tools like the $\mathrm{t} / \mathrm{s}$-norms or some averages or more sophisticated ones like the various ordered weighted average (OWA) operators (Yager, 1988; Yager, Kacprzyk, \& Beliakov, 2011). The approach was then extended by Kacprzyk (2015) and Kacprzyk, Romero, and Gomide (1999), and used for the modeling of regional development planning in many regions around the world. The OWA operators proposed in this paper can yield a new quality in a human consistent aggregation of such an assessment of stability which is clearly opposite to the volatility, and their application to the planning of regional development will be shown in next papers.

One way to add information to the volatility formula, is changing the usual average by adding weights and other tools. In this sense, we can use the ordered weighted average (OWA) operator, developed by Yager (1988) to generate new scenarios between the minimum and the maximum operator. Also, more complex operators using the OWA as a base have been studied by many authors (Yager et al., 2011; Emrouznejad \& Marra, 2014; BlancoMesa, Merigó, \& Gil-Lafuente, 2017). For example, the heavy OWA (HOWA) operator (Yager, 2002), where the weights are not bounded to the sum equal to 1, and the induced OWA (IOWA) operator (Yager \& Filev, 1999), where the weights are induced according to the characteristics of the decision makers.

The aim of this paper is to analyze the use of the OWA operator and some of its extensions in the volatility formula. The main advantage of doing this is that it is possible to generate new scenarios identifying different elements that the traditional formula can't include, such as an optimistic and pessimistic results. In this sense, we introduce new concepts of volatility like the OWMA-volatility, IOWMA-volatility, HOWMA-volatility and IHOWMA-volatility.

An application of these new formulas in foreign exchange market is also developed. We use exchange rate USD/MXN, EUR/MXN and EUR/USD information from 2015-2016 to forecast the volatility for all the months for the year 2016. The information provided by the different formulations is presented in tables and graphs for the analysis. 
The idea of these new operators and its application is in order to see that in economic markets that uncertainty is a common things and specifically in FOREX market that many of the signals that the market give to the investors and decision makers can be interpreted in many ways, the use of a formulation that will help them in order to include they expectations, knowledge and aptitude toward the market and obtain a result that include that characteristics give them a new approach and will help them to generate new strategies in order to minimize the risk or have a new vision where the market will led and make decisions based on that and not only in the traditional techniques that are usually based only in historical data and leave aside the qualitative information that we can have at the time when the decision is made.

The remainder of the paper is organized as follows. In Section 1, we review the volatility and some aggregation operators. Section 2 introduced different approaches of volatility using OWA operator as a base. Section 3 explains the steps for using the new volatility formulas, and Section 4 presents an application in USD/MXN exchange rate forecast. Last Section summarizes the main conclusions of the paper.

\section{Preliminaries}

In this section some basic concepts and definitions, such as volatility, aggregation operators, moving average operators and heavy moving average operators are presented.

\subsection{Volatility}

Since the collapse of the Bretton Woods agreement, exchange rate has presented an increasing volatility growing the risk that the companies have (Ethier, 1973; Héricourt \& Poncet, 2015). One way to calculate volatility is based on the coefficient of variation, this can be defined as follows.

Definition 1. Volatility formula is:

$$
v=\frac{\sigma}{\mu}
$$

where $v$ is volatility, $\sigma$ is standard deviation and $\mu$ is the average.

As it can be seen, the volatility formula integrates an average, in this sense we can introduce a more complex way of analysis by adding weights and other aggregation operators to the classical formulation.

\subsection{Aggregation operators}

The weighted average is one of the most common aggregation operators. The formulation is similar to the normal average but also includes a weight that multiplies each of the arguments. The definition is as follows (Merigó, Guillén, \& Sarabia, 2015).

Definition 2. A WA operator of dimension $n$ is a mapping WA: $R^{n} \rightarrow R$ that has an associated weighting vector $V$, with $v_{i} \in[0,1]$ and $\sum_{i=1}^{n} v_{i}=1$, such that 


$$
\mathrm{WA}\left(a_{1}, \ldots, a_{n}\right)=\sum_{i=1}^{n} v_{j} a_{j}
$$

where $a_{j}$ represent the arguments and $v_{j}$ is the weight related to that argument.

The OWA operator, is an extension of the WA operator, in the way that the weights can be rearranged according to different criteria, such as minimum, maximum, Laplace and Hurwicz. The definition is as follows (Yager, 1988).

Definition 3. An OWA operator of dimension $\mathrm{n}$ is a mapping OWA $: R^{n} \rightarrow R$ with an associated weight vector $W$ of dimension $\mathrm{n}$ such that $\sum_{j=1}^{n} w_{j}=1$ and $w_{j} \in[0,1]$, according to
the following formula:

$$
\operatorname{OWA}\left(a_{1}, a_{2}, \ldots, a_{n}\right)=\sum_{j=1}^{n} w_{j} b_{j}
$$

where $b_{j}$ is the jth largest element of the collection $a_{i}$.

The heavy OWA (HOWA) operator (Yager, 2002) is an extension of the traditional OWA, where the main characteristic of this new operator is in the weight vector, which is not bounded by the sum of 1 . This operator can be defined as follows.

Definition 4. A HOWA operator is a mapping HOWA : $R^{n} \rightarrow R$ associated to a weighting vector $W$ where $w_{j} \in[0,1]$ and $1 \leq \sum_{j=1}^{n} w_{j} \leq n$, such that

$$
\operatorname{HOWA}\left(a_{1}, a_{2}, \ldots, a_{n}\right)=\sum_{j=1}^{n} w_{j} b_{j}
$$

where $b_{j}$ is the jth largest element of the collection $a_{i}$.

The characteristics of the HOWA operator are that it is monotonic and commutative, but it is not bounded by the minimum and the maximum operator. With the possibility to expand the weighting vector from $-\infty$ to $\infty$, we can drastically under- or overestimate the results of the HOWA operator, considering new scenarios according to information of the decision maker and some expectations of the future of the case in study.

The induced OWA (IOWA) operator was introduced by Yager and Filev (1999) and the main difference is that the reordering step is developed with order inducing variables according to the information, knowledge and preference of the decision maker. The IOWA operator can be defined as follows.

Definition 5. An IOWA operator of dimension $n$ is an application IOWA $: R^{n} \times R^{n} \rightarrow R$ that has a weighting vector associated, $W$ of dimension $\mathrm{n}$ where the sum of the weights is 1 and $w_{j} \in[0,1]$, where an induced set of ordering variables are included $\left(u_{i}\right)$ such that the formula is

$$
\operatorname{IOWA}\left(u_{1}, a_{1}, u_{2}, a_{2}, \ldots, u_{n}, a_{n}\right)=\sum_{j=1}^{n} w_{j} b_{j},
$$

where $b_{j}$ is the $a_{i}$ value of the OWA pair $\left\langle u_{i}, a_{i}\right\rangle$ having the jth largest $u_{i} . u_{i}$ is the order inducing variable and $a_{i}$ is the argument variable. 


\subsection{Moving average operators}

A moving average is an averaging technique that has been used in economics and statistics. This technique is an average that moves toward some part of the sample. The moving average, according to Kenney and Keeping (1962) can be defined as follows.

Definition 6. A moving average is defined as a sequence given $\left\{a_{i}\right\}_{i=1}^{N}$, where a moving average $n$ is a new sequence $\left\{s_{i}\right\}_{i=1}^{N-n+1}$ defined from $a_{i}$ taking the arithmetic mean of the sequence of $n$ terms, such that

$$
s_{i}=\frac{1}{n} \sum_{j=i}^{i+n-1} a_{j}
$$

The usual moving average can be extended by using weighted averages, obtaining the weighted moving average (WMA). Merigó and Yager (2013) defined it as follows.

Definition 7. A weighted moving average (WMA) of dimension $\mathrm{m}$ is a mapping WMA : $R^{m} \rightarrow R$ that has an associated weighting vector $W$ of dimension $\mathrm{m}$ with $W=\sum_{i=1+t}^{m+t} w_{i}=1$ and $w_{i} \in[0,1]$, such that
$\operatorname{WMA}\left(a_{1+t}, a_{2+t}, \ldots, a_{m+t}\right)=\sum_{i=1+t}^{m+t} w_{i} a_{i}$,

where $a_{i}$ is the ith argument, $m$ is the total number of arguments considered from the whole sample and $t$ indicates the movement performed in the average from the initial analysis. Note that if $w_{i}=1 / m$ for all $i$, the WMA becomes the MA aggregation.

If weights are added to the WMA we obtained the ordered weighted moving average (OWMA). Merigó and Yager (2013) defined it as follows.

Definition 8. An ordered weighted moving average (OWMA) of dimension $m$ is a mapping OWMA : $R^{m} \rightarrow R$ that has an associated weighting vector $W$ of dimension $\mathrm{m}$ with $W=\sum_{j=1+t}^{m+t} w_{j}=1$ and $w_{j} \in[0,1]$, such that

$$
\operatorname{OWMA}\left(a_{1+t}, a_{2+t}, \ldots, a_{m+t}\right)=\sum_{j=1+t}^{m+t} w_{j} b_{j},
$$

where $b_{j}$ is the jth largest argument of the $a_{i}, \mathrm{~m}$ is the total number of arguments considered from the whole sample and $t$ indicates the movement in the average from the initial analysis.

Also, note it is possible to add an induced reordering step the induced weighted vector resulting in the IOWMA operator is generated. Merigó and Yager (2013) defined it as follows.

Definition 9. An IOWMA of dimension $m$ is a mapping IOWMA : $R^{M} \times R^{M} \rightarrow R$ that has an associated weighting vector $W$ of dimension $m$ with $W=\sum_{j=1+t}^{m+t} w_{j}=1$ and $w_{j} \in[0,1]$,
such that

$$
\operatorname{IOWMA}\left(u_{1+t}, a_{1+t}, u_{2+t}, a_{2+t}, \ldots, u_{m+t}, a_{m+t}\right)=\sum_{j=1+t}^{m+t} w_{j} b_{j},
$$

where $b_{j}$ is the $a_{i}$ value of the IOWMA pair $u_{i}, a_{i}$ having the $j$ th largest $u_{i}, u_{i}$ is the order inducing variable, $a_{i}$ is the argument variable, $m$ is the total number of arguments considered from the whole sample and $t$ indicates movement in the average from the initial analysis. 
If heavy weights are considered in the OWMA operator, the heavy ordered weighted moving average (HOWMA) operator is obtained. The definition is as follows (León-Castro, Avilés-Ochoa, \& Gil-Lafuente, 2016).

Definition 10. A HOWMA is defined as a sequence given $\left\{a_{i}\right\}_{i=1}^{N}$, where you get a new sequence $\left\{s_{i}\right\}_{i=1}^{N-n+1}$ which is multiplied by the heavy weight vector, so that

$$
\operatorname{HOWMA}\left(s_{i}\right)=\sum_{j=1}^{n} w_{j} b_{j}
$$

where $b_{j}$ is the $j$ th largest element of the collection $a_{1} a_{2}, \ldots, a_{n}$, and $W$ is an associated weighting vector of dimension $m$ that satisfies $1 \leq \sum_{i=1+t}^{m+t} w_{j} \leq n$ and $w_{j} \in[0,1]$. Observe that here we can also expand the weighting vector to the range $-\infty$ to $\infty$. Thus, the weighting vector $w$ becomes unbounded: $-\infty \leq \sum_{j=1}^{n} w_{j} \leq \infty$.

Considering the HOWMA operator and adding an induced reordering step, the induced heavy ordered weighted moving average (IHOWMA) operator is generated. León-Castro, Avilés-Ochoa, and Merigó (2018) defined it as follows.

Definition 11. A IHOWMA operator is defined as a given sequence $\left\{a_{i}\right\}_{i=1}^{N}$, where a new sequence $\left\{s_{i}\right\}_{i=1}^{N-m+1}$ is multiplied by a heavy weighting vector, such that

$$
\operatorname{IHOWMA}\left(u_{1+t}, a_{1+t}, u_{2+t}, a_{2+t}, \ldots, u_{n+t}, a_{m+t}\right)=\sum_{j=1+t}^{m+t} w_{j} b_{j},
$$

where $b_{j}$ is $j$ th element that has the largest value of $u_{i}, u_{i}$ is the order inducing variable, and $W$ is an associated weighting vector of dimension $m$ with $W: 1 \leq \sum_{i=1+t}^{m+t} w_{j} \leq n$ and $w_{j} \in[0,1]$. Observe that we can also expand the weighting vector like in the case of the HOWMA operator.

\section{Heavy moving average operators in the volatility}

In order to include knowledge and experience of the decision maker in the traditional volatility formula, we consider different aggregation operators that will change the part of the usual average of the formula. First, we consider the OWMA operator with volatility, the definition is as follows.

Definition 12. An OWMA - Volatility operator of dimension $m$ is a mapping OWMA - Volatility: $R^{m} \rightarrow R$ that has an associated weighting vector $W$ of dimension $m$ with $W=\sum_{j=1+t}^{m+t} w_{j}=1$ and $w_{j} \in[0,1]$, such that

$$
\text { OWMA - Volatility }\left(a_{1+t}, a_{2+t}, \ldots, a_{m+t}\right)=\frac{\sigma-\mathrm{OWMA}}{\mu-\mathrm{OWMA}},
$$

where $\sigma-$ OWMA is the OWMA standard deviation, $\mu-$ OWMA is the OWMA average. 
Considering an induced reordering step in the OWMA - Volatility, the IOWMA - Volatility is proposed. The definition is.

Definition 13. An IOWMA - Volatility of dimension $\mathrm{m}$ is a mapping IOWMA - Volatility: $R^{M} \times R^{M} \rightarrow R$ that has an associated weighting vector $W$ of dimension $m$ with $W=\sum_{j=1+t}^{m+t} w_{j}=1$ and $w_{j} \in[0,1]$, such that

$$
\text { IOWMA - Volatility }\left(u_{1+t}, a_{1+t}, \ldots, u_{m+t}, a_{m+t}\right)=\frac{\sigma-\text { IOWMA }}{\mu-\text { IOWMA }},
$$

where $\sigma-$ IOWA is IOWMA standard deviation and $\mu$-IOWMA is IOWMA average.

Also, if the weights are not bounded by 1 , the HOWMA-Volatility is generated and the definition is.

Definition 14. A HOWMA - Volatility is defined as a sequence given $\left\{a_{i}\right\}_{i=1}^{N}$, where you get a new sequence $\left\{s_{i}\right\}_{i=1}^{N-n+1}$ which is associated with a weight vector $w$ with $w_{j} \in[0,1]$ and $1 \leq \sum_{j=1}^{n} w_{j} \leq n$, so that $\operatorname{HOWMA}-\operatorname{Volatility}\left(s_{i}\right)=\frac{\sigma-\text { HOWMA }}{\mu-\text { HOWMA }}$,

where $\sigma-$ HOWMA is HOWMA standard deviation and $\mu-$ HOWMA is HOWMA average.

Finally, if a reordering step in the weights is used, the IHOWMA-Volatility is presented. The definition is as follows.

Definition 15. A IHOWMA - Volatility operator is defined as a given sequence $\left\{a_{i}\right\}_{i=1}^{N}$, where a new sequence $\left\{s_{i}\right\}_{i=1}^{N-m+1}$ which is associated with a weight vector $w$ with $w_{j} \in[0,1]$ and $1 \leq \sum_{j=1}^{n} w_{j} \leq n$, so that

$$
\text { IHOWMA - Volatility }\left(u_{1+t}, a_{1+t}, \ldots, u_{n+t}, a_{m+t}\right)=\frac{\sigma-\text { IHOWMA }}{\mu-\text { IHOWMA }}
$$

where $\sigma$-IHOWMA is IHOWMA standard deviation and $\mu-$ IHOWMA is IHOWMA average.

The properties for the OWMA - Volatility and IOWMA - Volatility are the followings (The proofs are trivial and thus omitted): a) Commutative: Assume $f$ is the OWMA - Volatility or IOWMA - Volatility operator, the $f\left(u_{i}, a_{i}, \ldots, u_{n}, a_{n}\right)=f\left(u_{i}, b_{i}, \ldots, u_{n}, b_{n}\right)$. Monotonicity: Assume $f$ is the OWMA - Volatility or IOWMA-Volatility operator; if $\left|u_{i}, a_{i}\right| \geq\left|u_{i}, b_{i}\right|$ for all $i_{i}$, then $f\left(u_{i}, a_{i}, \ldots, u_{n}, a_{n}\right) \geq f\left(u_{i}, b_{i}, \ldots, u_{n}, b_{n}\right)$. Bounded: Assume $f$ is the OWMA - Volatility or IOWMA - Volatility operator, then $\min \left\{a_{i}\right\} \leq f\left(u_{i}, a_{i}, \ldots, u_{n}, a_{n}\right) \leq \max \left\{a_{i}\right\}$. Idempotency: Assume $f$ is the OWMA - Volatility or IOWMA - Volatility operator; if $\left|u_{i}, a_{i}\right|=a$ for all $i$, then $f\left(u_{i}, a_{i}, \ldots, u_{n}, a_{n}\right)=a$. Also, note that HOWMA - Volatility and IHOWMA - Volatility operators have as properties commutative, monotonicity and idempotency, they are not bounded because the weighting vector can range $1 \leq \sum_{j=1}^{n} w_{j} \leq n$.

Also note that all formulas have 2 particular cases. One considering an attitude in the standard deviation and not in the average and another one considering an attitude in the average and not in the standard deviation. These cases are presented in Table 1. 
Table 1. Volatility operators and their particular cases

\begin{tabular}{|l|c|c|c|}
\hline \multicolumn{1}{|c|}{ Operator } & General & Case 1 & Case 2 \\
\hline OWMA - Volatility & $\frac{\sigma-\text { OWMA }}{\mu-\text { OWMA }}$ & $\frac{\sigma}{\mu-\text { OWMA }}$ & $\frac{\sigma \text {-OWMA }}{\mu}$ \\
\hline IOWMA - Volatility & $\frac{\sigma-\text { IOWMA }}{\mu-\text { IOWMA }}$ & $\frac{\sigma}{\mu-\text { IOWMA }}$ & $\frac{\sigma-\text { IOWMA }}{\mu}$ \\
\hline HOWMA - Volatility & $\frac{\sigma-\text { HOWMA }}{\mu-\text { HOWMA }}$ & $\frac{\sigma}{\mu-\text { HOWMA }}$ & $\frac{\sigma-\text { HOWMA }}{\mu}$ \\
\hline IHOWMA - Volatility & $\frac{\sigma-\text { IHOWMA }}{\mu-\text { IHOWMA }}$ & $\frac{\sigma}{\mu-\text { IHOWMA }}$ & $\frac{\sigma-\text { IHOWMA }}{\mu}$ \\
\hline
\end{tabular}

To understand better each of the cases that are explained in Table 1, the new formulations of standard deviation are defined.

Definition 16. The $\sigma-O W M A$ is defined as follows:

$$
\sigma-\operatorname{OWMA}\left(a_{1+t}, a_{2+t}, \ldots, a_{i+t}, \ldots, a_{m+t}\right)=\sum_{j=1+t}^{m+t} \sqrt{w_{j}\left[D_{j}^{2}\right]}
$$

where $D_{j}$ is the jth largest argument of the $\left(a_{i+t}-\bar{x}\right), \bar{x}$ is the median (or average) of the sample, $m$ is the total number of arguments considered from the whole sample and $t$ indicates the movement in the average from the initial analysis.

Definition 17. The $\sigma$-IOWMA formulation is:

$$
\sigma-\operatorname{IOWMA}\left(u_{1+t}, a_{1+t}, \ldots, u_{m+t}, a_{m+t}\right)=\sum_{j=1+t}^{m+t} \sqrt{w_{j}\left[D_{j}^{2}\right]},
$$

where $D_{j}$ is the $\left(a_{i+t}-\bar{x}\right)$ value of the IOWMA pair $u_{i}, a_{i}$ having the $j$ th largest $u_{i}, u_{i}$ is the order inducing variable, $a_{i}$ is the argument variable, $\bar{x}$ is the median of the sample, $m$ is the total number of arguments considered from the whole sample and $t$ indicates movement in the average from the initial analysis.

Definition 18. The $\sigma-$ HOWMA is defined as:

$$
\sigma-\operatorname{HOWMA}\left(a_{1+t}, a_{2+t}, \ldots, a_{m+t}\right)=\sum_{j=1+t}^{m+t} \sqrt{w_{j}\left[D_{j}^{2}\right]},
$$

where $D_{j}$ is the jth largest argument of the $\left(a_{i+t}-\bar{x}\right), \bar{x}$ is the median of the sample, $m$ is the total number of arguments considered from the whole sample, $t$ indicates the movement in the average from the initial analysis, $w$ is an associated weighting vector of dimension $m$ that satisfies $1 \leq \sum_{i=1+t}^{m+t} w_{j} \leq n$ and $w_{j} \in[0,1]$. Observe that here we can also expand the weighting vector to the range $-\infty$ to $\infty$. Thus, the weighting vector $w$ becomes unbounded: $-\infty \leq \sum_{j=1}^{n} w_{j} \leq \infty$ 
Definition 19. The $\sigma-I H O W M A$ is formulated as:

$$
\sigma-\operatorname{IHOWMA}\left(u_{1+t}, a_{1+t}, \ldots, u_{m+t}, a_{m+t}\right)=\sum_{j=1+t}^{m+t} \sqrt{w_{j}\left[D_{j}^{2}\right]}
$$

where $D_{j}$ is the $\left(a_{i+t}-\bar{x}\right)$ value of the IHOWMA pair $u_{i}, a_{i}$ having the $j$ th largest $u_{i}, u_{i}$ is the order inducing variable, $a_{i}$ is the argument variable, $\bar{x}$ is the median of the sample, $m$ is the total number of arguments considered from the whole sample, $t$ indicates the movement in the average from the initial analysis, $w$ is an associated weighting vector of dimension $m$ that satisfies $1 \leq \sum_{i=1+t}^{m+t} w_{j} \leq n$ and $w_{j} \in[0,1]$. Observe that here we can also expand the weighting vector to the range $-\infty$ to $\infty$. Thus, the weighting vector $w$ becomes unbounded: $-\infty \leq \sum_{j=1}^{n} w_{j} \leq \infty$.

In order to explain these new approaches better, we present a simple numerical example.

Example 1. The exchange rate USD/MXN for 2015 and 2016 is as follow (see Table 2).

Table 2. Exchange rate USD/MXN for 2015-2016

\begin{tabular}{|c|c|c|}
\hline Month & 2015 & 2016 \\
\hline January & 14.6808 & 18.0255 \\
\hline February & 14.9231 & 18.4777 \\
\hline March & 15.2136 & 17.6923 \\
\hline April & 15.2208 & 17.4905 \\
\hline May & 15.2475 & 18.0980 \\
\hline June & 15.4692 & 18.6506 \\
\hline July & 15.9225 & 18.5862 \\
\hline August & 16.5032 & 18.4715 \\
\hline September & 16.8519 & 19.1955 \\
\hline October & 16.5813 & 18.9157 \\
\hline November & 16.6325 & 20.0371 \\
\hline December & 16.9437 & 20.5156 \\
\hline
\end{tabular}

With this information, we calculate volatility for 2016 using the following information:

1. A weighted vector $W=(0.05,0.05,0.05,0.07,0.07,0.07,0.10,0.10,0.10,0.10,0.12,0.12)$;

2. An induced vector $U=(12,11,10,9,8,7,6,5,4,3,2,1)$;

3. A heavy weighted vector $W=(0.05,0.05,0.05,0.07,0.07,0.10,0.10,0.10,0.10,0.15,0.15)$.

The results are as follows (see Tables 3-5). 
Table 3. Volatility for USD/MXN 2016 using the general formulation

\begin{tabular}{|l|c|c|c|c|c|}
\hline \multicolumn{1}{|c|}{ Month } & Volatility & $\begin{array}{c}\text { OWMA- } \\
\text { Volatility }\end{array}$ & $\begin{array}{c}\text { IOWMA- } \\
\text { Volatility }\end{array}$ & $\begin{array}{c}\text { HOWMA- } \\
\text { Volatility }\end{array}$ & $\begin{array}{c}\text { IHOWMA- } \\
\text { Volatility }\end{array}$ \\
\hline January & 0.0514 & 0.0502 & 0.0486 & 0.0500 & 0.0477 \\
\hline February & 0.0584 & 0.0552 & 0.0568 & 0.0545 & 0.0572 \\
\hline March & 0.0656 & 0.0612 & 0.0645 & 0.0604 & 0.0656 \\
\hline April & 0.0638 & 0.0609 & 0.0607 & 0.0610 & 0.0606 \\
\hline May & 0.0587 & 0.0577 & 0.0536 & 0.0584 & 0.0516 \\
\hline June & 0.0536 & 0.0539 & 0.0493 & 0.0545 & 0.0477 \\
\hline July & 0.0504 & 0.0494 & 0.0479 & 0.0492 & 0.0473 \\
\hline August & 0.0468 & 0.0453 & 0.0444 & 0.0444 & 0.0440 \\
\hline September & 0.0447 & 0.0445 & 0.0403 & 0.0442 & 0.0394 \\
\hline October & 0.0473 & 0.0476 & 0.0429 & 0.0482 & 0.0423 \\
\hline November & 0.0432 & 0.0442 & 0.0392 & 0.0452 & 0.0389 \\
\hline December & 0.0445 & 0.0423 & 0.0433 & 0.0422 & 0.0435 \\
\hline
\end{tabular}

Table 4. Volatility for USD/MXN 2016 using the case 1 formulation

\begin{tabular}{|l|c|c|c|c|c|}
\hline \multicolumn{1}{|c|}{ Month } & Volatility & $\begin{array}{c}\text { OWMA- } \\
\text { Volatility }\end{array}$ & $\begin{array}{c}\text { IOWMA- } \\
\text { Volatility }\end{array}$ & $\begin{array}{c}\text { HOWMA- } \\
\text { Volatility }\end{array}$ & $\begin{array}{c}\text { IHOWMA- } \\
\text { Volatility }\end{array}$ \\
\hline January & 0.0514 & 0.0495 & 0.0492 & 0.0521 & 0.0514 \\
\hline February & 0.0584 & 0.0544 & 0.0578 & 0.0567 & 0.0619 \\
\hline March & 0.0656 & 0.0601 & 0.0657 & 0.0628 & 0.0712 \\
\hline April & 0.0638 & 0.0599 & 0.0617 & 0.0633 & 0.0655 \\
\hline May & 0.0587 & 0.0569 & 0.0544 & 0.0607 & 0.0556 \\
\hline June & 0.0536 & 0.0532 & 0.0500 & 0.0568 & 0.0513 \\
\hline July & 0.0504 & 0.0487 & 0.0486 & 0.0513 & 0.0509 \\
\hline August & 0.0468 & 0.0447 & 0.0449 & 0.0464 & 0.0474 \\
\hline September & 0.0447 & 0.0441 & 0.0407 & 0.0462 & 0.0422 \\
\hline October & 0.0473 & 0.0471 & 0.0434 & 0.0503 & 0.0455 \\
\hline November & 0.0432 & 0.0437 & 0.0396 & 0.0472 & 0.0417 \\
\hline December & 0.0445 & 0.0419 & 0.0437 & 0.0441 & 0.0467 \\
\hline
\end{tabular}


Table 5. Volatility for USD/MXN 2016 using the case 2 formulation

\begin{tabular}{|l|c|c|c|c|c|}
\hline \multicolumn{1}{|c|}{ Month } & Volatility & $\begin{array}{c}\text { OWMA- } \\
\text { Volatility }\end{array}$ & $\begin{array}{c}\text { IOWMA- } \\
\text { Volatility }\end{array}$ & $\begin{array}{c}\text { HOWMA- } \\
\text { Volatility }\end{array}$ & $\begin{array}{c}\text { IHOWMA- } \\
\text { Volatility }\end{array}$ \\
\hline January & 0.0514 & 0.0522 & 0.0507 & 0.0494 & 0.0477 \\
\hline February & 0.0584 & 0.0593 & 0.0575 & 0.0561 & 0.0540 \\
\hline March & 0.0656 & 0.0667 & 0.0644 & 0.0632 & 0.0605 \\
\hline April & 0.0638 & 0.0649 & 0.0628 & 0.0615 & 0.0590 \\
\hline May & 0.0587 & 0.0596 & 0.0579 & 0.0565 & 0.0545 \\
\hline June & 0.0536 & 0.0544 & 0.0529 & 0.0515 & 0.0499 \\
\hline July & 0.0504 & 0.0511 & 0.0497 & 0.0483 & 0.0468 \\
\hline August & 0.0468 & 0.0474 & 0.0463 & 0.0448 & 0.0435 \\
\hline September & 0.0447 & 0.0451 & 0.0442 & 0.0427 & 0.0416 \\
\hline October & 0.0473 & 0.0479 & 0.0468 & 0.0453 & 0.0441 \\
\hline November & 0.0432 & 0.0437 & 0.0427 & 0.0413 & 0.0402 \\
\hline December & 0.0445 & 0.0450 & 0.0441 & 0.0426 & 0.0415 \\
\hline
\end{tabular}

\section{Generalizations of the IHOWMA - Volatility}

In this section, the use of quasi-arithmetic is used in order to generalize the formulation and present some interesting particular cases (Yager, 2004; Merigó \& Gil-Lafuente, 2009; Zhou \& Chen, 2011). To understand better these new formulations the whole formula will be explained (instead of using $\sigma$-IHOWMA and $\mu$-IHOWMA as simplification for example). The Quasi-IHOWMA-Volatility formulation is as follows.

Definition 20. A Quasi - IHOWMA - Volatility operator is defined as a given sequence $\left\{a_{i}\right\}_{i=1}^{N}$, where a new sequence $\left\{s_{i}\right\}_{i=1}^{N-m+1}$ which is associated with a weight vector $w$ with $w_{j} \in[0,1]$ and $1 \leq \sum_{j=1}^{n} w_{j} \leq n$, so that

Quasi - IHOWMA - Volatility $\left(u_{1+t}, a_{1+t}, \ldots, u_{n+t}, a_{m+t}\right)=g^{-1}\left(\frac{\sum_{j=1+t}^{m+t} \sqrt{w_{j}\left[\left(g\left(D_{j}\right)^{2}\right]\right.}}{\sum_{j=1+t}^{m+t} w_{j} g\left(b_{j}\right)}\right)$,

where $b_{j}$ is the $a_{i+t}$ and $D_{j}$ is the $\left(a_{i+t}-\bar{x}\right)$ value of the IHOWMA pair $u_{i+t}, a_{i+t}$ having the $j$ th largest $u_{i}, u_{i}$ is the order inducing variable, $a_{i}$ is the argument variable, $\bar{x}$ is the median of the sample, $m$ is the total number of arguments considered from the whole sample, $t$ indicates the movement in the average from the initial analysis, $g$ and $h$ are strictly continuous monotone functions, $w$ is an associated weighting vector of dimension $m$ that satisfies 
$1 \leq \sum_{i=1+t}^{m+t} w_{j} \leq n$ and $w_{j} \in[0,1]$. Observe that here we can also expand the weighting vector to the range $-\infty$ to $\infty$. Thus, the weighting vector $w$ becomes unbounded: $-\infty \leq \sum_{j=1}^{n} w_{j} \leq \infty$.

Also, is possible to generalize the OWMA-volatility, IOWMA-volatility and HOWMAvolatility operators by using quasi-arithmetic means. These formulations are as follows.

Definition 21. A Quasi-HOWMA-Volatility operator is defined as a given sequence $\left\{a_{i}\right\}_{i=1}^{N}$ ' where a new sequence $\left\{s_{i}\right\}_{i=1}^{N-m+1}$ which is associated with a weight vector $w$ with $w_{j} \in[0,1]$ and $1 \leq \sum_{j=1}^{n} w_{j} \leq n$, so that

$$
\text { Quasi - HOWMA - Volatility }\left(a_{1+t}, \ldots, a_{m+t}\right)=g^{-1}\left(\frac{\sum_{j=1+t}^{m+t} \sqrt{w_{j}\left[\left(g\left(D_{j}\right)^{2}\right]\right.}}{\sum_{j=1+t}^{m+t} w_{j} g\left(b_{j}\right)}\right),
$$

where $b_{j}$ is the $j$ th largest argument of the $a_{i+t}$ and $D_{j}$ is the $j$ th largest argument of the $\left(a_{i+t}-\bar{x}\right), \bar{x}$ is the median of the sample, $m$ is the total number of arguments considered from the whole sample, $t$ indicates the movement in the average from the initial analysis, $g$ and $h$ are strictly continuous monotone functions, $w$ is an associated weighting vector of dimension $m$ that satisfies $1 \leq \sum_{i=1+t}^{m+t} w_{j} \leq n$ and $w_{j} \in[0,1]$. Observe that here we can also expand the weighting vector to the range $-\infty$ to $\infty$. Thus, the weighting vector $w$ becomes unbounded: $-\infty \leq \sum_{j=1}^{n} w_{j} \leq \infty$.

Definition 22. A Quasi-IOWMA-Volatility operator is defined as a given sequence $\left\{a_{i}\right\}_{i=1}^{N}$, where a new sequence $\left\{s_{i}\right\}_{i=1}^{N-m+1}$ which is associated with a weight vector $w$ with $w_{j} \in[0,1]$ and $1 \leq \sum_{j=1}^{n} w_{j} \leq n$, so that

$$
\text { Quasi-IOWMA - Volatility }\left(u_{1+t}, a_{1+t}, \ldots, u_{n+t}, a_{m+t}\right)=g^{-1}\left(\frac{\sum_{j=1+t}^{m+t} \sqrt{w_{j}\left[\left(g\left(D_{j}\right)^{2}\right]\right.}}{\sum_{j=1+t}^{m+t} w_{j} g\left(b_{j}\right)}\right) \text {, }
$$

where $b_{j}$ is the $a_{i+t}$ and $D_{j}$ is the $\left(a_{i+t}-\bar{x}\right)$ value of the IOWMA pair $u_{i}, a_{i}$ having the $j$ th largest $u_{i}, u_{i}$ is the order inducing variable, $a_{i}$ is the argument variable, $\bar{x}$ is the median of the sample, $m$ is the total number of arguments considered from the whole sample, $t$ indicates the movement in the average from the initial analysis and $g$ and $h$ are strictly continuous monotone functions.

Definition 23. A Quasi-OWMA-Volatility operator is defined as a given sequence $\left\{a_{i}\right\}_{i=1}^{N}$, where a new sequence $\left\{s_{i}\right\}_{i=1}^{N-m+1}$ which is associated with a weight vector $w$ with $w_{j} \in[0,1]$ and $1 \leq \sum_{j=1}^{n} w_{j} \leq n$, so that 


$$
\text { Quasi - OWMA - Volatility }\left(a_{1+t}, \ldots, a_{m+t}\right)=g^{-1}\left(\frac{\sum_{j=1+t}^{m+t} \sqrt{w_{j}\left[\left(g\left(D_{j}\right)^{2}\right]\right.}}{\sum_{j=1+t}^{m+t} w_{j} g\left(b_{j}\right)}\right) \text {, }
$$

where $b_{j}$ is the $j$ th largest argument of the $a_{i+t}$ and $D_{j}$ is the $j$ th largest argument of the $\left(a_{i+t}-\bar{x}\right), \bar{x}$ is the median of the sample, $m$ is the total number of arguments considered from the whole sample, $t$ indicates the movement in the average from the initial analysis and $g$ and $h$ are strictly continuous monotone functions.

In Table 6, there are present some of the main particular cases of the Quasi - IHOWMA volatility.

Table 6. Families of generalized IHOWMA volatility

\begin{tabular}{|l|l|}
\hline \multicolumn{1}{|c|}{ Particular case } & \multicolumn{1}{c|}{ Quasi-IHOWMA - volatility } \\
\hline$p_{i}=\frac{1}{n}$, for all $i$ & $\begin{array}{l}\text { Quasi-arithmetic induced ordered weighted moving } \\
\text { average volatility (Quasi - HOWMA - volatility) }\end{array}$ \\
\hline$w_{i}=\frac{1}{n}$, for all $i$ & $\begin{array}{l}\text { Quasi-arithmetic induced heavy moving average volatility } \\
\text { (Quasi - IHMA - volatility) }\end{array}$ \\
\hline$h(D)=D^{\lambda}, g(b)=b^{\lambda}$ & Generalized IHOWMA - volatility \\
\hline$h(D)=D, g(b)=b$ & IHOWMA - volatility \\
\hline$h(D)=D^{2}, g(b)=b^{2}$ & $\begin{array}{l}\text { Induced heavy ordered weighted quadratic moving } \\
\text { average volatility (IHOWQMA - volatility) }\end{array}$ \\
\hline$h(D) \rightarrow D^{\lambda}, g(b) \rightarrow b^{\lambda}$, for $\lambda \rightarrow 0$ & $\begin{array}{l}\text { Induced heavy ordered weighted geometric moving } \\
\text { average volatility (IHOWGMA - volatility) }\end{array}$ \\
\hline$h(D)=D^{-1}, g(b)=b^{-1}$ & $\begin{array}{l}\text { Induced heavy ordered weighted harmonic moving } \\
\text { average volatility (IHOWHMA - volatility) }\end{array}$ \\
\hline$h(D)=D^{3}, g(b)=b^{3}$ & $\begin{array}{l}\text { Induced heavy ordered weighted cubic moving } \\
\text { average volatility (IHOWCMA - volatility) }\end{array}$ \\
\hline$h(D) \rightarrow D^{\lambda}, g(b) \rightarrow b^{\lambda}$, for $\lambda \rightarrow \infty$ & Maximum operator \\
\hline$h(D) \rightarrow D^{\lambda}, g(b) \rightarrow b^{\lambda}$, for $\lambda \rightarrow-\infty$ & Minimum operator \\
\hline
\end{tabular}

\section{IHOWMA-Volatility with EUR/MXN and EUR/USD exchange rate}

\subsection{Theoretical approach}

The study of the volatility has been applied in different assets clases such as foreign exchange markets, equity, bond and many more (Carr \& Wu, 2008; Mueller, Vedolin, \& Yen, 2012; Della Corte, Ramadorai, \& Sarno, 2016). Among the largest and important financial market in the world is the foreign exchange market, that is why forecasting volatility is relevant to 
organizations, financial institutions and traders wanting to do risk management strategies (Pilbeam \& Langeland, 2015).

Different techniques have been used in order to forecast volatility, in this paper we present a new approach using as base the classical formulation of volatility (standard deviation and average) and different OWA operator extensions, specifically the IHOWMA operator and some of its particular cases such as the HOWMA, IOWMA and OWMA operators. Also, three different volatility formulations have been presented adding the information in the standard deviation (case 1) or in the average (case 2). The steps to use these new OWA volatility operators in foreign exchange rate are as follow.

Step 1. It is necessary to identified the large of the moving average that will be used to forecast volatility, it can be twelve months (1 year), six months (Half year) or three months (A quarter).

Step 2. The information of the exchange rate currencies that want to be evaluated.

Step 3. The weighting vector that will be applied to the arguments based in the importance of the information and the decision maker knowledge. It is important to note, for the Heavy weights it can range from $-\infty$ to $\infty$, this is done when the decision maker wants to underestimate or overestimate the results.

Step 4. The induced vector that will be used to order the weights according to the expectations of the decision maker has to be identified.

Step 5 . With the information provided by Step 1 to 5 , now it is important to define which of the different OWA-volatility formulations will be made (General, case 1 or case 2).

Step 6. An analysis has to be done about the information obtained by the different operators and volatility formulations.

\subsection{Numerical example}

Step 1. The large of the moving average will be twelve months

Step 2. The exchange rate that will be analyzed will be EUR/MXN and EUR/USD for 2016 (see Tables 7-8).

Step 3. A weighted vector

$W=(0.05,0.05,0.05,0.07,0.07,0.07,0.10,0.10,0.10,0.10,0.12,0.12)$.

And a heavy weighted vector

$W=(0.05,0.05,0.05,0.07,0.07,0.10,0.10,0.10,0.10,0.15,0.15)$.

Step 4. An induced vector $U=(12,11,10,9,8,7,6,5,4,3,2,1)$.

Step 5. For both cases (EUR/MXN and EUR/USD) the three OWA-Volatility formulation (General, case 1 and case 2) and the OWMA, IOWMA, HOWMA and IHOWMA operators will be applied (see Tables 9-14). 
Table 7. Exchange rate EUR/MXN for 2015-2016

\begin{tabular}{|l|c|c|}
\hline \multicolumn{1}{|c|}{ Month } & 2015 & 2016 \\
\hline January & 16.8343 & 20.4321 \\
\hline February & 16.8269 & 20.0299 \\
\hline March & 16.3233 & 19.7873 \\
\hline April & 16.6941 & 19.8733 \\
\hline May & 17.0320 & 20.6288 \\
\hline June & 17.4147 & 20.9361 \\
\hline July & 17.5338 & 20.5435 \\
\hline August & 18.3213 & 20.7234 \\
\hline September & 18.9434 & 21.2936 \\
\hline October & 18.8437 & 21.3345 \\
\hline November & 18.1610 & 21.0676 \\
\hline December & 18.0803 & 21.7698 \\
\hline
\end{tabular}

Table 8. Exchange rate EUR/USD for 2015-2016

\begin{tabular}{|l|c|c|}
\hline \multicolumn{1}{|c|}{ Month } & 2015 & 2016 \\
\hline January & 1.1387 & 1.1026 \\
\hline February & 1.1138 & 1.1041 \\
\hline March & 1.0781 & 1.1274 \\
\hline April & 1.0900 & 1.1355 \\
\hline May & 1.1150 & 1.1270 \\
\hline June & 1.1241 & 1.1240 \\
\hline July & 1.1006 & 1.1063 \\
\hline August & 1.1110 & 1.1200 \\
\hline September & 1.1254 & 1.1201 \\
\hline October & 1.1277 & 1.1110 \\
\hline November & 1.0925 & 1.0895 \\
\hline December & 1.0767 & 1.0599 \\
\hline
\end{tabular}

Table 9. Volatility for EUR/MXN 2016 using the general formulation

\begin{tabular}{|l|c|c|c|c|c|}
\hline \multicolumn{1}{|c|}{ Month } & Volatility & $\begin{array}{c}\text { OWMA - } \\
\text { Volatility }\end{array}$ & $\begin{array}{c}\text { IOWMA- } \\
\text { Volatility }\end{array}$ & $\begin{array}{c}\text { HOWMA- } \\
\text { Volatility }\end{array}$ & $\begin{array}{c}\text { IHOWMA- } \\
\text { Volatility }\end{array}$ \\
\hline January & 0.0497 & 0.0476 & 0.0464 & 0.0461 & 0.0443 \\
\hline February & 0.0650 & 0.0612 & 0.0636 & 0.0605 & 0.0641 \\
\hline March & 0.0695 & 0.0661 & 0.0676 & 0.0662 & 0.0685 \\
\hline April & 0.0651 & 0.0619 & 0.0617 & 0.0620 & 0.0608 \\
\hline
\end{tabular}


End of Table 9

\begin{tabular}{|l|c|c|c|c|c|}
\hline \multicolumn{1}{|c|}{ Month } & Volatility & $\begin{array}{c}\text { OWMA- } \\
\text { Volatility }\end{array}$ & $\begin{array}{c}\text { IOWMA- } \\
\text { Volatility }\end{array}$ & $\begin{array}{c}\text { HOWMA- } \\
\text { Volatility }\end{array}$ & $\begin{array}{c}\text { IHOWMA- } \\
\text { Volatility }\end{array}$ \\
\hline May & 0.0604 & 0.0585 & 0.0567 & 0.0585 & 0.0551 \\
\hline June & 0.0590 & 0.0575 & 0.0562 & 0.0576 & 0.0551 \\
\hline July & 0.0585 & 0.0572 & 0.0557 & 0.0569 & 0.0552 \\
\hline August & 0.0528 & 0.0516 & 0.0497 & 0.0501 & 0.0488 \\
\hline September & 0.0509 & 0.0503 & 0.0460 & 0.0486 & 0.0445 \\
\hline October & 0.0532 & 0.0543 & 0.0465 & 0.0542 & 0.0456 \\
\hline November & 0.0531 & 0.0561 & 0.0462 & 0.0582 & 0.0454 \\
\hline December & 0.0437 & 0.0460 & 0.0378 & 0.0474 & 0.0368 \\
\hline
\end{tabular}

Table 10. Volatility for EUR/MXN 2016 using the case 1 formulation

\begin{tabular}{|l|c|c|c|c|c|}
\hline \multicolumn{1}{|c|}{ Month } & Volatility & $\begin{array}{c}\text { OWMA- } \\
\text { Volatility }\end{array}$ & $\begin{array}{c}\text { IOWMA- } \\
\text { Volatility }\end{array}$ & $\begin{array}{c}\text { HOWMA- } \\
\text { Volatility }\end{array}$ & $\begin{array}{c}\text { IHOWMA- } \\
\text { Volatility }\end{array}$ \\
\hline January & 0.0497 & 0.0470 & 0.0470 & 0.0482 & 0.0476 \\
\hline February & 0.0650 & 0.0603 & 0.0647 & 0.0630 & 0.0693 \\
\hline March & 0.0695 & 0.0650 & 0.0689 & 0.0687 & 0.0744 \\
\hline April & 0.0651 & 0.0608 & 0.0627 & 0.0644 & 0.0657 \\
\hline May & 0.0604 & 0.0577 & 0.0574 & 0.0610 & 0.0593 \\
\hline June & 0.0590 & 0.0567 & 0.0570 & 0.0600 & 0.0594 \\
\hline July & 0.0585 & 0.0563 & 0.0566 & 0.0592 & 0.0597 \\
\hline August & 0.0528 & 0.0510 & 0.0502 & 0.0524 & 0.0525 \\
\hline September & 0.0509 & 0.0498 & 0.0465 & 0.0509 & 0.0478 \\
\hline October & 0.0532 & 0.0536 & 0.0472 & 0.0566 & 0.0491 \\
\hline November & 0.0531 & 0.0553 & 0.0468 & 0.0606 & 0.0489 \\
\hline December & 0.0437 & 0.0455 & 0.0382 & 0.0496 & 0.0394 \\
\hline
\end{tabular}

Table 11. Volatility for EUR/MXN 2016 using the case 2 formulation

\begin{tabular}{|l|c|c|c|c|c|}
\hline \multicolumn{1}{|c|}{ Month } & Volatility & $\begin{array}{c}\text { OWMA- } \\
\text { Volatility }\end{array}$ & $\begin{array}{c}\text { IOWMA- } \\
\text { Volatility }\end{array}$ & $\begin{array}{c}\text { HOWMA- } \\
\text { Volatility }\end{array}$ & $\begin{array}{c}\text { IHOWMA- } \\
\text { Volatility }\end{array}$ \\
\hline January & 0.0497 & 0.0503 & 0.0491 & 0.0476 & 0.0463 \\
\hline February & 0.0650 & 0.0661 & 0.0640 & 0.0625 & 0.0602 \\
\hline March & 0.0695 & 0.0707 & 0.0682 & 0.0670 & 0.0640 \\
\hline April & 0.0651 & 0.0662 & 0.0641 & 0.0627 & 0.0603 \\
\hline May & 0.0604 & 0.0612 & 0.0596 & 0.0579 & 0.0560 \\
\hline June & 0.0590 & 0.0599 & 0.0582 & 0.0567 & 0.0548 \\
\hline July & 0.0585 & 0.0594 & 0.0576 & 0.0563 & 0.0542 \\
\hline August & 0.0528 & 0.0534 & 0.0522 & 0.0505 & 0.0491 \\
\hline September & 0.0509 & 0.0514 & 0.0503 & 0.0486 & 0.0474 \\
\hline October & 0.0532 & 0.0538 & 0.0525 & 0.0510 & 0.0494 \\
\hline November & 0.0531 & 0.0538 & 0.0524 & 0.0510 & 0.0493 \\
\hline December & 0.0437 & 0.0442 & 0.0433 & 0.0418 & 0.0408 \\
\hline
\end{tabular}


Table 12. Volatility for EUR/USD 2016 using the general formulation

\begin{tabular}{|c|c|c|c|c|c|}
\hline Month & Volatility & $\begin{array}{c}\text { OWMA- } \\
\text { Volatility }\end{array}$ & $\begin{array}{c}\text { IOWMA- } \\
\text { Volatility }\end{array}$ & $\begin{array}{c}\text { HOWMA- } \\
\text { Volatility }\end{array}$ & $\begin{array}{c}\text { IHOWMA- } \\
\text { Volatility }\end{array}$ \\
\hline January & 0.0182 & 0.0175 & 0.0171 & 0.0171 & 0.0170 \\
\hline February & 0.0160 & 0.0152 & 0.0155 & 0.0150 & 0.0153 \\
\hline March & 0.0158 & 0.0152 & 0.0149 & 0.0150 & 0.0141 \\
\hline April & 0.0150 & 0.0140 & 0.0148 & 0.0135 & 0.0142 \\
\hline May & 0.0155 & 0.0138 & 0.0160 & 0.0132 & 0.0156 \\
\hline June & 0.0160 & 0.0146 & 0.0162 & 0.0140 & 0.0158 \\
\hline July & 0.0160 & 0.0155 & 0.0150 & 0.0148 & 0.0144 \\
\hline August & 0.0157 & 0.0156 & 0.0146 & 0.0148 & 0.0139 \\
\hline September & 0.0158 & 0.0159 & 0.0143 & 0.0152 & 0.0136 \\
\hline October & 0.0156 & 0.0159 & 0.0133 & 0.0155 & 0.0126 \\
\hline November & 0.0151 & 0.0163 & 0.0126 & 0.0165 & 0.0120 \\
\hline December & 0.0154 & 0.0159 & 0.0137 & 0.0160 & 0.0133 \\
\hline
\end{tabular}

Table 13. Volatility for EUR/USD 2016 using the case 1 formulation

\begin{tabular}{|l|c|c|c|c|c|}
\hline \multicolumn{1}{|c|}{ Month } & Volatility & $\begin{array}{c}\text { OWMA- } \\
\text { Volatility }\end{array}$ & $\begin{array}{c}\text { IOWMA- } \\
\text { Volatility }\end{array}$ & $\begin{array}{c}\text { HOWMA- } \\
\text { Volatility }\end{array}$ & $\begin{array}{c}\text { IHOWMA- } \\
\text { Volatility }\end{array}$ \\
\hline January & 0.0182 & 0.0175 & 0.0171 & 0.0182 & 0.0179 \\
\hline February & 0.0160 & 0.0152 & 0.0155 & 0.0159 & 0.0162 \\
\hline March & 0.0158 & 0.0152 & 0.0149 & 0.0159 & 0.0149 \\
\hline April & 0.0150 & 0.0140 & 0.0148 & 0.0143 & 0.0151 \\
\hline May & 0.0155 & 0.0139 & 0.0160 & 0.0140 & 0.0166 \\
\hline June & 0.0160 & 0.0146 & 0.0162 & 0.0148 & 0.0167 \\
\hline July & 0.0160 & 0.0155 & 0.0151 & 0.0156 & 0.0153 \\
\hline August & 0.0157 & 0.0156 & 0.0146 & 0.0157 & 0.0148 \\
\hline September & 0.0158 & 0.0159 & 0.0143 & 0.0161 & 0.0144 \\
\hline October & 0.0156 & 0.0159 & 0.0133 & 0.0164 & 0.0134 \\
\hline November & 0.0151 & 0.0162 & 0.0127 & 0.0174 & 0.0127 \\
\hline December & 0.0154 & 0.0159 & 0.0137 & 0.0169 & 0.0141 \\
\hline
\end{tabular}

Table 14. Volatility for EUR/USD 2016 using the case 2 formulation

\begin{tabular}{|l|c|c|c|c|c|}
\hline \multicolumn{1}{|c|}{ Month } & Volatility & $\begin{array}{c}\text { OWMA- } \\
\text { Volatility }\end{array}$ & $\begin{array}{c}\text { IOWMA- } \\
\text { Volatility }\end{array}$ & $\begin{array}{c}\text { HOWMA- } \\
\text { Volatility }\end{array}$ & $\begin{array}{c}\text { IHOWMA- } \\
\text { Volatility }\end{array}$ \\
\hline January & 0.0182 & 0.0182 & 0.0182 & 0.0171 & 0.0172 \\
\hline February & 0.0160 & 0.0160 & 0.0160 & 0.0151 & 0.0151 \\
\hline March & 0.0158 & 0.0158 & 0.0158 & 0.0149 & 0.0149 \\
\hline April & 0.0150 & 0.0150 & 0.0150 & 0.0141 & 0.0141 \\
\hline May & 0.0155 & 0.0155 & 0.0155 & 0.0146 & 0.0146 \\
\hline
\end{tabular}


End of Table 14

\begin{tabular}{|l|c|c|c|c|c|}
\hline \multicolumn{1}{|c|}{ Month } & Volatility & $\begin{array}{c}\text { OWMA- } \\
\text { Volatility }\end{array}$ & $\begin{array}{c}\text { IOWMA- } \\
\text { Volatility }\end{array}$ & $\begin{array}{c}\text { HOWMA- } \\
\text { Volatility }\end{array}$ & $\begin{array}{c}\text { IHOWMA- } \\
\text { Volatility }\end{array}$ \\
\hline June & 0.0160 & 0.0160 & 0.0160 & 0.0151 & 0.0151 \\
\hline July & 0.0160 & 0.0160 & 0.0160 & 0.0151 & 0.0151 \\
\hline August & 0.0157 & 0.0158 & 0.0157 & 0.0149 & 0.0148 \\
\hline September & 0.0158 & 0.0158 & 0.0158 & 0.0149 & 0.0149 \\
\hline October & 0.0156 & 0.0156 & 0.0155 & 0.0147 & 0.0147 \\
\hline November & 0.0151 & 0.0151 & 0.0151 & 0.0143 & 0.0142 \\
\hline December & 0.0154 & 0.0154 & 0.0154 & 0.0146 & 0.0145 \\
\hline
\end{tabular}

Step 6. Taking into account example 1 (USD/MXN) and the information presented in section 6.2 of this paper (EUR/MXN and EUR/USD) it is possible to note that with the use of different aggregation operators different perspectives for the volatility according if the attitude is given to both standard deviation and average or to one of them can be done. With this it is possible to generate new strategies for risk management according to this new data. For simplify the analysis a graph for the three cases for the general formulation of the OWA-Volatility is presented (see Figures 1-3).

If we analyze the data, it is possible to see that for example the month with more volatility for USD/MXN is march and can range from 0.0601 (OWMA with case 1) to 0.0878 (IHOWMA with case 2), in the case of the EUR/MXN is also march and can range from 0.0640 (IHOWMA with case 2) to 0.0744 (IHOWMA with case 1) and for EUR/USD is January and range from 0.0170 (IHOWMA with general case) to 0.0182 (Volatility). These information is relevant because can be used to different things like speculation, risk management strategy, take decision about buying or selling your products in an specific month of the year and many more (as can be seen there are different levels of volatility among different currencies so it is possible to make approaches where you can buy USD/MXN and then get them back from EUR/USD and change it back to EUR/MXN). Finally, it is important to take in account that with all these new scenarios it is possible to increase the knowledge of the financial market and explain in a better way how they will be in the future.

Additionally, a matrix with scatterplot graphs is presented (see Figure 4) to make a comparison between each of the methods, in a common way, it is found that each of these has a positive relationship, which is obvious derived from using the same data series as base. The interesting thing is in how there are relations that show a strength of relationship not as strong as is the case of IOWMA volatility and the HOWMA volatility and on the other hand we find strong relationships such as those presented with the IOWMA volatility and the IHOWMA volatility. This analysis is important because it allows us to find how the use of different operators can generate results with different interpretations and that they can differ from each other even when the same data is used to analyze. 


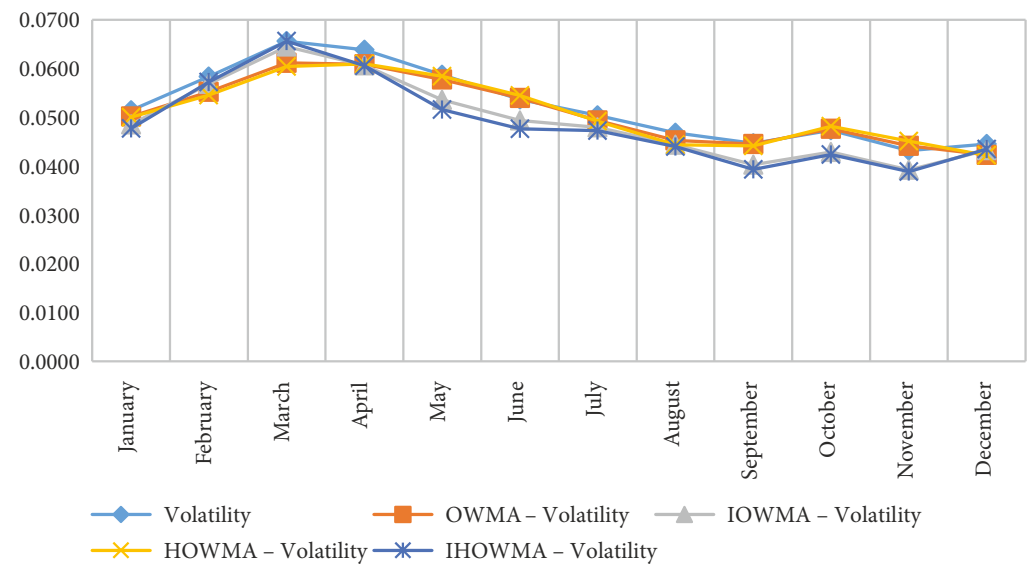

Figure 1. USD/MXN 2016 volatility by different operators for general formulation

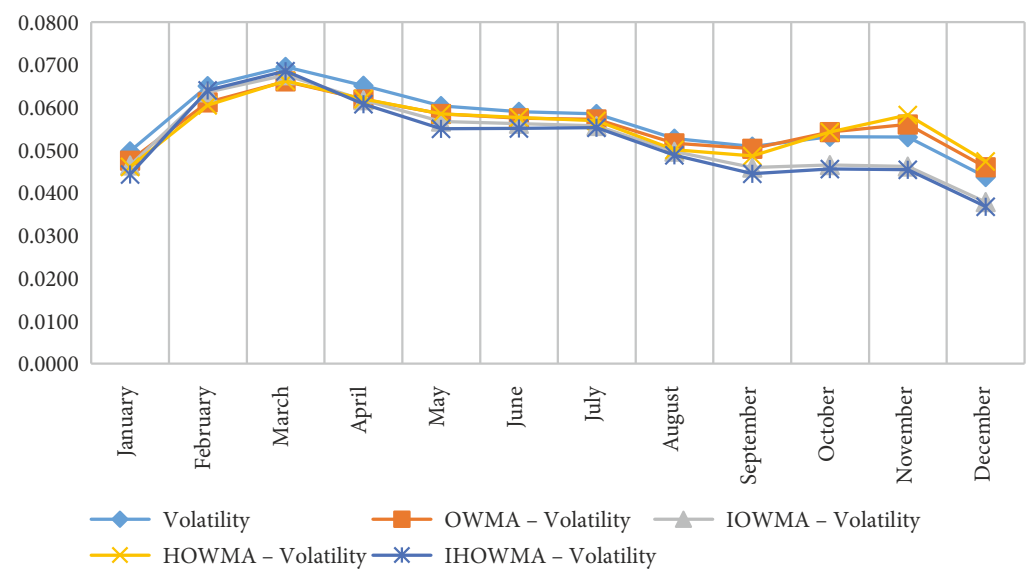

Figure 2. EUR/MXN 2016 volatility by different operators for general formulation

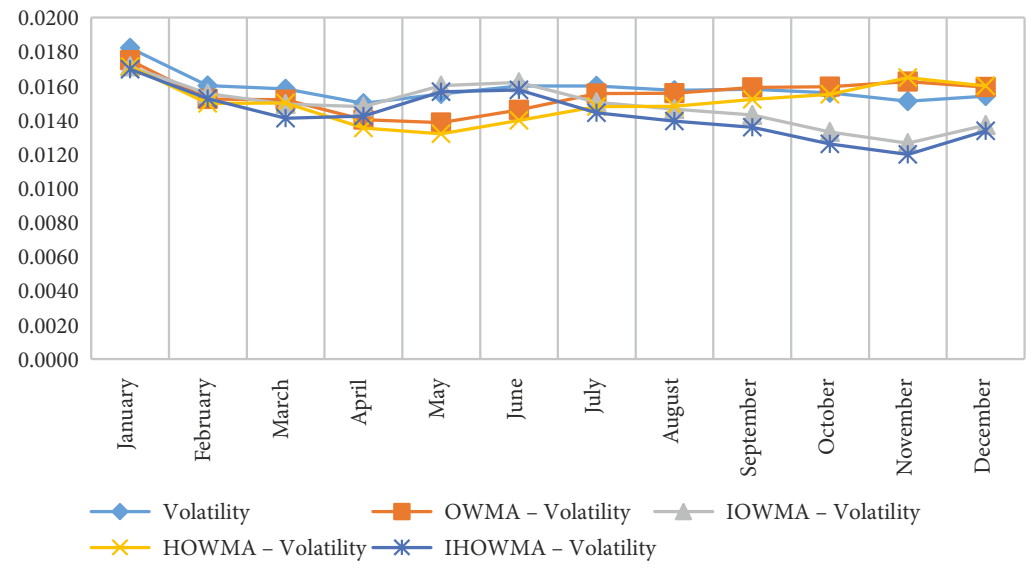

Figure 3. EUR/USD 2016 volatility by different operators for general formulation 


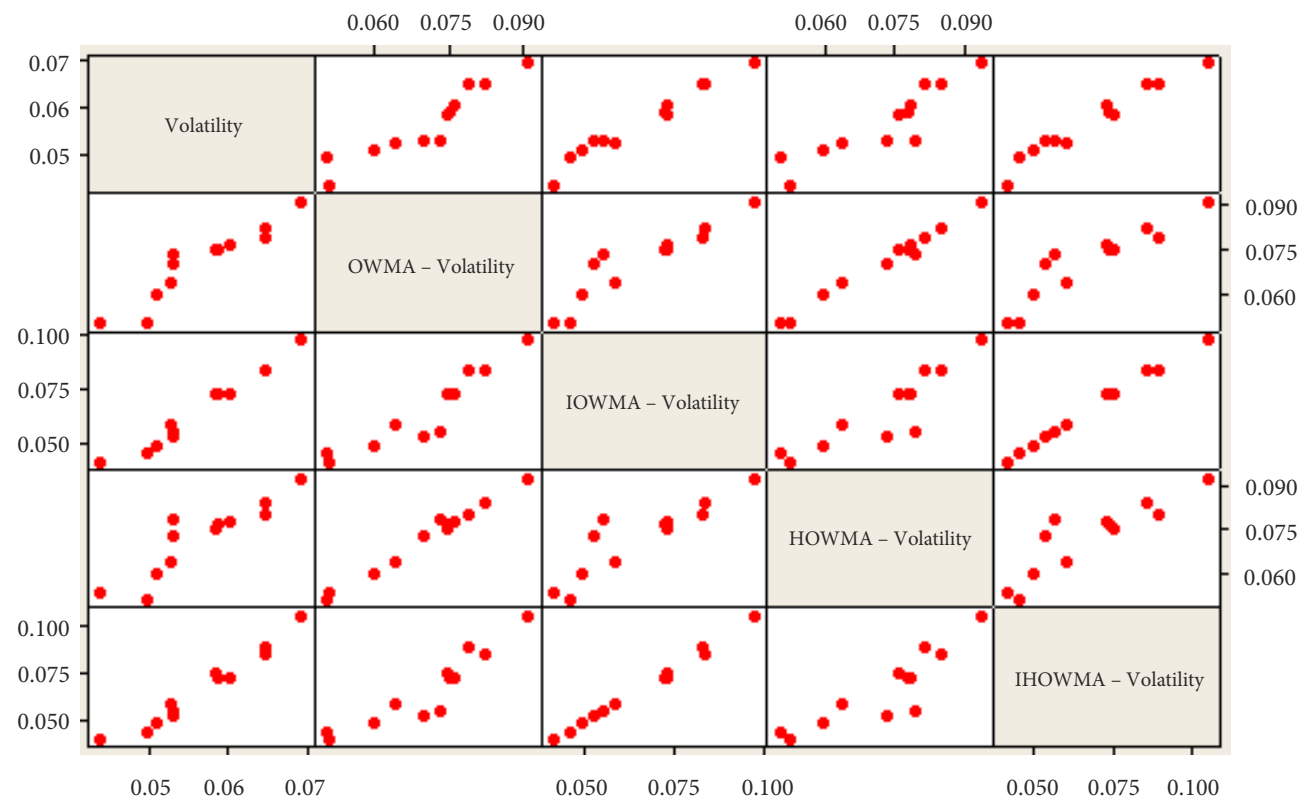

Figure 4. Matrix with scatterplot graphs for each method

\section{Conclusions}

The paper introduced an extension of the classical formulation of the volatility called the induced heavy ordered weighted moving average (IHOWMA) volatility. This extension includes the characteristics of the IHOWMA operator in the standard deviation and/or average that are the components of the classical volatility formula, in this sense, it is possible to aggregate the knowledge, experience and expectative of the decision maker by the use of an induced-order variable and a heavy weighting vector.

The definition and some of the families of the IHOWMA-volatility operator are presented. Those ranges of families are the OWMA-volatility, IOWMA-volatility and HOWMAvolatility. Additionally, three different formulations are presented: 1) General formulation where the aggregation process is used in both the standard deviation and the average, 2) Case 1 formulation where the process is only applied to the standard deviation and 3) Case 2 formulation where the aggregation is done in the average only.

An application of this extension is used in foreign exchange rate market. The forecast of the volatility for 2016 for the USD/MXN, EUR/MXN and EUR/USD currencies are presented. As can be seen with the use of the different operators the volatility between the currencies can change, these kind of information is very important because when we analyze the FOREX market it is important to note that not every agent interpreted the information in the same way. In these sense, the use of aggregation operators can help us to have a better idea of how can things can change if we include different aspects of the decision maker or the market into the formulation and in this way generate a better risk management strategy and these is the most important aspect of these new formulations, have a new approach of 
the future and know that the market can have different results and interpretations is very important in the economics markets that are characterized for its uncertainty.

In future research, we plan to make more extensions of aggregation operators using prioritized operators (Pérez-Arellano, León-Castro, Avilés-Ochoa, \& Merigó 2017; Avilés-Ochoa, Perez-Arellano, León-Castro, \& Merigó, 2017), Bonferroni means (Blanco-Mesa, Merigó, \& Kacprzyk, 2016; Blanco-Mesa, León-Castro, \& Merigó, 2018; Y. He, Z. He, \& Chen, 2015), Choquet integrals (Belles-Sampera, Merigó, Guillén, \& Santolino, 2014), distance operators (Merigó \& Casanovas, 2011; Liu \& Chen, 2017), Hesitant fuzzy sets (Ren, Xu, \& Hao, 2017; Zeng \& Yao, 2018), intuitionistic fuzzy sets (Liu, J. X. You, X. Y. You, \& Su, 2016), multicriteria decision making (Zeng, Chen, \& Li, 2016) and econometric techniques (León-Castro, Avilés-Ochoa, Merigó, \& Gil-Lafuente, 2018; Avilés-Ochoa, León-Castro, Gil-Lafuente, \& Merigó, 2018). Additionally, we will also use other operators in different kinds of problems like group decision making $(\mathrm{Xu}, 2006)$. Also, the development of the formulation for the OWA volatility and some of its extensions and families have been planned for future research, the main difference is that instead of using the moving average in the aggregation process, the information will be evaluated individually.

We plan to use the powerful OWA type aggregation operators to further extend our models of the broadly perceived decision making in socio-economic systems to obtain a deeper insight of the stability of regional development strategies as already mentioned (Kacprzyk \& Straszak, 1984; Yager et al., 2011; Kacprzyk, 2015). Moreover, we plan to further extend the use of our operators for a human consistent aggregation of preferences, testimonies and judgments under a fuzzy majority proposed in Kacprzyk (1986). In particular, we will deal with various classes of group decisions (Zeng, Llopis-Albert, \& Zhang, 2018; Merigó, Xu, \& Zeng, 2013) and voting (Kacprzyk, Fedrizzi, \& Nurmi, 1992), and consensus reaching (Herrera-Viedma, Cabrerizo, Kacprzyk, \& Pedrycz, 2014; Kacprzyk \& Fedrizzi, 1988, 1989; Kacprzyk, Zadrożny, \& Raś, 2010).

\section{Acknowledgements}

The paper is supported by "Red Iberoamericana para la Competitividad, Innovación y Desarrollo" (REDCID) project number 616RT0515 in "Programa Iberoamericano de Ciencia y Tecnología para el Desarrollo" (CYTED).

\section{References}

Aristotelous, K. (2001). Exchange-rate volatility, exchange-rate regime, and trade volume: evidence from the UK-US export function (1889-1999). Economics Letters, 72(1), 87-94. https://doi.org/10.1016/S0165-1765(01)00414-1

Avilés-Ochoa, E., León-Castro, E., Gil-Lafuente, A. M., \& Merigó, J. M. (2018). Forgotten effects in exchange rate forecasting models. In Complex systems: solutions and challenges in economics, management and engineering (pp. 423-437). Cham: Springer.

Avilés-Ochoa, E., Perez-Arellano, L. A., León-Castro, E., \& Merigó, J. M. (2017). Prioritized induced probabilistic distances in transparency and access to information laws. Fuzzy Economic Review, 22(1). https://doi.org/10.25102/fer.2017.01.04 
Belles-Sampera, J., Merigó, J. M., Guillén, M., \& Santolino, M. (2014). Indicators for the characterization of discrete Choquet integrals. Information Sciences, 267, 201-216.

https://doi.org/10.1016/j.ins.2014.01.047

Blanco-Mesa, F., León-Castro, E., \& Merigó, J. M. (2018). Bonferroni induced heavy operators in ERM decision-making: A case on large companies in Colombia. Applied Soft Computing, 72, 371-391. https://doi.org/10.1016/j.asoc.2018.08.001

Blanco-Mesa, F., Merigó, J. M., \& Gil-Lafuente, A. M. (2017). Fuzzy decision making: a bibliometricbased review. Journal of Intelligent \& Fuzzy Systems, 32(3), 2033-2050.

https://doi.org/10.3233/JIFS-161640

Blanco-Mesa, F., Merigó, J. M., \& Kacprzyk, J. (2016). Bonferroni means with distance measures and the adequacy coefficient in entrepreneurial group theory. Knowledge-Based Systems, 111, 217-227. https://doi.org/10.1016/j.knosys.2016.08.016

Carr, P., \& Wu, L. (2008). Variance risk premiums. The Review of Financial Studies, 22(3), 1311-1341. https://doi.org/10.1093/rfs/hhn038

Della Corte, P., Ramadorai, T., \& Sarno, L. (2016). Volatility risk premia and exchange rate predictability. Journal of Financial Economics, 120(1), 21-40. https://doi.org/10.1016/j.jfineco.2016.02.015

Emrouznejad, A., \& Marra, M. (2014). Ordered weighted averaging operators 1988-2014: A citationbased literature survey. International Journal of Intelligent Systems, 29(11), 994-1014.

https://doi.org/10.1002/int.21673

Ethier, W. (1973). International trade and the forward exchange market. The American Economic Review, 63(3), 494-503.

Garman, M. B., \& Klass, M. J. (1980). On the estimation of security price volatilities from historical data. Journal of business, 67-78. https://doi.org/10.1086/296072

Grossmann, A., Love, I., \& Orlov, A. G. (2014). The dynamics of exchange rate volatility: A panel VAR approach. Journal of International Financial Markets, Institutions and Money, 33, 1-27. https://doi.org/10.1016/j.intfin.2014.07.008

He, Y., He, Z., \& Chen, H. (2015). Intuitionistic fuzzy interaction Bonferroni means and its application to multiple attribute decision making. IEEE transactions on cybernetics, 45(1), 116-128.

https://doi.org/10.1109/TCYB.2014.2320910

Héricourt, J., \& Poncet, S. (2015). Exchange rate volatility, financial constraints, and trade: empirical evidence from Chinese firms. The World Bank Economic Review, 29(3), 550-578. https://doi.org/10.1093/wber/lht035

Herrera-Viedma, E., Cabrerizo, F. J., Kacprzyk, J., \& Pedrycz, W. (2014). A review of soft consensus models in a fuzzy environment. Information Fusion, 17, 4-13.

https://doi.org/10.1016/j.inffus.2013.04.002

Hooghe, M., \& Kern, A. (2015). Party membership and closeness and the development of trust in political institutions: An analysis of the European Social Survey, 2002-2010. Party Politics, 21(6), 944-956. https://doi.org/10.1177/1354068813509519

Kacprzyk, J. (1986). Group decision making with a fuzzy linguistic majority. Fuzzy sets and systems, 18(2), 105-118. https://doi.org/10.1016/0165-0114(86)90014-X

Kacprzyk, J. (2015). Fuzzy dynamic programming for the modeling of sustainable regional development (Survey). Applied and Computational Mathematics, 14(2), 107-124.

Kacprzyk, J., \& Fedrizzi, M. (1988). A 'soft'measure of consensus in the setting of partial (fuzzy) preferences. European Journal of Operational Research, 34(3), 316-325.

https://doi.org/10.1016/0377-2217(88)90152-X

Kacprzyk, J., \& Fedrizzi, M. (1989). A 'human-consistent'degree of consensus based on fuzzy login with linguistic quantifiers. Mathematical Social Sciences, 18(3), 275-290.

https://doi.org/10.1016/0165-4896(89)90035-8 
Kacprzyk, J., \& Straszak, A. (1984). Determination of "stable" trajectories of integrated regional development using fuzzy decision models. IEEE Transactions on Systems, Man, and Cybernetics, 14(2), 310-313. https://doi.org/10.1109/TSMC.1984.6313215

Kacprzyk, J., Fedrizzi, M., \& Nurmi, H. (1992). Group decision making and consensus under fuzzy preferences and fuzzy majority. Fuzzy Sets and Systems, 49(1), 21-31.

https://doi.org/10.1016/0165-0114(92)90107-F

Kacprzyk, J., Romero, R. A., \& Gomide, F. A. (1999). Involving objective and subjective aspects in multistage decision making and control under fuzziness: dynamic programming and neural networks. International Journal of Intelligent Systems, 14(1), 79-104. https://doi.org/10.1002/(SICI)1098-111X(199901)14:1<79::AID-INT6>3.0.CO;2-6

Kacprzyk, J., Zadrożny, S., \& Raś, Z. W. (2010). How to support consensus reaching using action rules: a novel approach. International Journal of Uncertainty, Fuzziness and Knowledge-Based Systems, 18(04), 451-470. https://doi.org/10.1142/S0218488510006647

Kenney, J., \& Keeping, E. (1962). Moving Averages. Princeton: Van Nostrand.

León-Castro, E., Avilés-Ochoa, E. A., \& Gil-Lafuente, A. M. (2016). Exchange rate USD/MXN forecast through econometric models, time series and HOWMA operators. Economic Computation and Economic Cybernetics Studies and Research, 50(4), 135-150.

León-Castro, E., Avilés-Ochoa, E., \& Merigó, J. M. (2018). Induced heavy moving averages. International Journal of Intelligent Systems, 33(9), 1823-1839. https://doi.org/10.1002/int.21916

León-Castro, E., Avilés-Ochoa, E., Merigó, J. M., \& Gil-Lafuente, A. M. (2018). Heavy moving averages and their application in econometric forecasting. Cybernetics and Systems, 49(1), 26-43. https://doi.org/10.1080/01969722.2017.1412883

Liu, H. C., You, J. X., You, X. Y., \& Su, Q. (2016). Fuzzy Petri nets using intuitionistic fuzzy sets and ordered weighted averaging operators. IEEE Transactions on Cybernetics, 46(8), 1839-1850. https://doi.org/10.1109/TCYB.2015.2455343

Liu, P., \& Chen, S. M. (2017). Group decision making based on Heronian aggregation operators of intuitionistic fuzzy numbers. IEEE Transactions on Cybernetics, 47(9), 2514-2530. https://doi.org/10.1109/TCYB.2016.2634599

Merigó, J. M., \& Casanovas, M. (2011). Decision-making with distance measures and induced aggregation operators. Computers \& Industrial Engineering, 60(1), 66-76. https://doi.org/10.1016/j.cie.2010.09.017

Merigó, J. M., \& Gil-Lafuente, A. M. (2009). The induced generalized OWA operator. Information Sciences, 179(6), 729-741. https://doi.org/10.1016/j.ins.2008.11.013

Merigó, J. M., \& Yager, R. R. (2013). Generalized moving averages, distance measures and OWA operators. International Journal of Uncertainty, Fuzziness and Knowledge-Based Systems, 21(04), 533-559. https://doi.org/10.1142/S0218488513500268

Merigó, J. M., Guillén, M., \& Sarabia, J. M. (2015). The ordered weighted average in the variance and the covariance. International Journal of Intelligent Systems, 30(9), 985-1005. https://doi.org/10.1002/int.21716

Merigó, J. M., Xu, Y., \& Zeng, S. (2013). Group decision making with distance measures and probabilistic information. Knowledge-Based Systems, 40, 81-87. https://doi.org/10.1016/j.knosys.2012.11.014

Minton, B. A., \& Schrand, C. (1999). The impact of cash flow volatility on discretionary investment and the costs of debt and equity financing. Journal of Financial Economics, 54(3), 423-460. https://doi.org/10.1016/S0304-405X(99)00042-2

Mueller, P., Vedolin, A., \& Yen, Y. M. (2012). Bond variance risk premia. Financial Markets Group, London School of Economics and Political Science. 
Officer, R. R. (1973). The variability of the market factor of the New York Stock Exchange. The Journal of Business, 46(3), 434-453. https://doi.org/10.1086/295551

Pérez-Arellano, L. A., León-Castro, E., Avilés-Ochoa, E., \& Merigó, J. M. (2017). Prioritized induced probabilistic operator and its application in group decision making. International Journal of Machine Learning and Cybernetics, 1-12.

Pilbeam, K., \& Langeland, K. N. (2015). Forecasting exchange rate volatility: GARCH models versus implied volatility forecasts. International Economics and Economic Policy, 12(1), 127-142. https://doi.org/10.1007/s10368-014-0289-4

Rabbani, A. G., Grable, J. E., Heo, W., Nobre, L., \& Kuzniak, S. (2017). Stock market volatility and changes in financial risk tolerance during the great recession. Journal of Financial Counseling and Planning, 28(1), 140. https://doi.org/10.1891/1052-3073.28.1.140

Ren, P., Xu, Z., \& Hao, Z. (2017). Hesitant fuzzy thermodynamic method for emergency decision making based on prospect theory. IEEE Transactions on Cybernetics, 47(9), 2531-2543. https://doi.org/10.1109/TCYB.2016.2638498

Zeng, S., \& Xiao, Y. (2018). A method based on TOPSIS and distance measures for hesitant fuzzy multiple attribute decision making. Technological and Economic Development of Economy, 24(3), 969-983. https://doi.org/10.3846/20294913.2016.1216472

Van Biezen, I., Mair, P., \& Poguntke, T. (2012). Going, going,... gone? The decline of party membership in contemporary Europe. European Journal of Political Research, 51(1), 24-56. https://doi.org/10.1111/j.1475-6765.2011.01995.x

$\mathrm{Xu}, \mathrm{Z}$. (2006). Induced uncertain linguistic OWA operators applied to group decision making. Information Fusion, 7(2), 231-238. https://doi.org/10.1016/j.inffus.2004.06.005

Yager, R. R. (1988). On ordered weighted averaging aggregation operators in multicriteria decisionmaking. IEEE Transactions on Systems, Man, and Cybernetics, 18(1), 183-190. https://doi.org/10.1109/21.87068

Yager, R. R. (1996). On the inclusion of variance in decision making under uncertainty. International Journal of Uncertainty, Fuzziness and Knowledge-Based Systems, 4(05), 401-419. https://doi.org/10.1142/S0218488596000238

Yager, R. R. (2002). Heavy OWA operators. Fuzzy Optimization and Decision Making, 1(4), 379-397. https://doi.org/10.1023/A:1020959313432

Yager, R. R. (2004). Generalized OWA aggregation operators. Fuzzy Optimization and Decision Making, 3(1), 93-107. https://doi.org/10.1023/B:FODM.0000013074.68765.97

Yager, R. R. (2006). Generalizing variance to allow the inclusion of decision attitude in decision making under uncertainty. International Journal of Approximate Reasoning, 42(3), 137-158.

https://doi.org/10.1016/j.ijar.2005.09.001

Yager, R. R., \& Filev, D. P. (1999). Induced ordered weighted averaging operators. IEEE Transactions on Systems, Man, and Cybernetics, Part B (Cybernetics), 29(2), 141-150. https://doi.org/10.1109/3477.752789

Yager, R. R., Kacprzyk, J., \& Beliakov, G. (Eds.). (2011). Recent developments in the ordered weighted averaging operators: theory and practice (Vol. 265). Berlin, Heidelberg: Springer. https://doi.org/10.1007/978-3-642-17910-5

Zeng, S., Chen, J., \& Li, X. (2016). A hybrid method for pythagorean fuzzy multiple-criteria decision making. International Journal of Information Technology \& Decision Making, 15(02), 403-422. https://doi.org/10.1142/S0219622016500012

Zeng, S., Llopis-Albert, C., \& Zhang, Y. (2018). A novel induced aggregation method for intuitionistic fuzzy set and its application in multiple attribute group decision making. International Journal of Intelligent Systems, 33(11), 2175-2188. https://doi.org/10.1002/int.22009

Zhou, L. G., \& Chen, H. Y. (2011). Continuous generalized OWA operator and its application to decision making. Fuzzy Sets and Systems, 168(1), 18-34. https://doi.org/10.1016/j.fss.2010.05.009 